\title{
Main Character's Personality Conflict in Aladdin Movie
}

\author{
Nolen \\ Universitas Putera Batam, Batam, Indonesia \\ pb161210033@upbatam.ac.id
}

\author{
Tomi Arianto \\ Universitas Putera Batam, Batam, Indonesia \\ tomi.arianto@puterabatam.ac.id
}

\begin{abstract}
Abstrak: Dalam jurnal ini bertujuan untuk menemukan konfilk kepribadian karakter utama yang direpresentasikan melalui id, ego, dan superego dominan yang terdapat dalam karakter Aladdin dalam film Aladdin. Dalam makalah ini digunakan teori psikologi Sigmund Freud yang menyatakan bahwa ada tiga struktur yang dapat membentuk watak seseorang. Tiga struktur tersebut yaitu id, ego, dan superego. Penulis menggunakan metode deskriptif untuk menjelaskan id, ego, dan superego dalam karakter Aladdin. Penulis memperoleh data dari menonton film Aladdin yang dirilis pada tahun 1992, kemudian mencatat dan memberi tanda dimana karakter Aladdin menunjukkan sisi id, ego, dan superegonya. Hasil dari penelitian ini adalah id Aladdin terdapat disaat Aladdin bermimpi ingin menjadikan hidupnya lebih baik dan watak Aladdin yang tegar meskipun dihina oleh orang sekitar. Dalam penelitian ini penulis berharap agar penelitian ini berguna dan membantu untuk siapapun yang membaca, khususnya dalam karya sastra.
\end{abstract}

Kata Kunci: Id, Ego, Superego, Teori Sigmund Freud, Watak.

Abstract: In this journal aims to find the main character's personality conflict reflected from id, ego, and superego dominant that contained in Aladdin's character in film Aladdin. In this paper, the writer will use psychological theory of Sigmund Freud that states that there are three striking features that can shape a person's character. The three structures are id, ego, and superego. The author uses descriptive methods to explain the id, ego, and superego in the Aladdin character. The author obtained data from watching Aladdin which was released in 1992, then recorded and gave a sign where the character of Aladdin showed the id, ego, and superhero side. The results of this study are that Aladdin was present when Aladdin dreamed he wanted to make his life better and his character was strong despite being insulted by people around him. In this study the authors hope that this research is useful and helpful for anyone who reads, especially in literary works.

Keywords: Id, Ego, Superego, Sigmund Freud's theory, Character. 


\section{Introduction}

Literature is the art of written works produced by many researchers. Literature also is a certain scholar field as a record of where humans feel, human experiences, and human's thought. The human experience was from their activities and life and religion, cultures, politic, society or even in education. There are many literary works such as a movie, story, novel, drama, and poetry. Those are types of literature that have a deep relationship in human life which can be seen clearly from all literature that reflects the condition of human life. Each literature itself has the social background, in literature work also has moral or messages, psychological and also biographical that the author or writer is telling about their own experiences and give the readers some value to learn in life.

Nowadays people who enjoy the movies are increasing day by day, watching the movie in the studio or also using some electronics to watch some movie in literary work, such as mobile phone, laptop and computer. There are variety genres in movie that showed how the creativity of literary works, such as, tragedy genre, romance, historical and many others. In movie there are always has main character to start the story, the main character plays an important role in a literary work. Movie also has a close relationship with psychology, especially the character in the movie. Psychology is a study of human behavior was applied in analyzing human personalities or character personalities that involved in the movie. In literature, most authors using psychology analysis to analyze the character of person or writer or the paper that related with psychoanalytic. Lye stated analyzing texts, the psychoanalytic theory could be utilized to interpret the concealed meaning within a text, or to better understand the author's intention (Lye, 1996) means that from psychoanalysis the others authors could interpret the character in a literary work. For example that the authors got from the Aladdin (1992) movie is when Aladdin tried to cover the truth about his real life from Jasmine, Aladdin even has a fight with his Genie.

"Aladdin: Because of you. The only reason anyone thinks I'm worth anything is because of you. What if they find out I'm not really a prince? What if Jasmine finds out? I'd lose her. Genie, I can't keep this up on my own. I can't wish you free " (Clements R. \&., 1992).

The Aladdin's character in the conversation above showed that Aladdin's selfishness or Ego is rising and tried to disclaim his promise to Genie before.

In this study the authors is going to analyze the main character in movie called Aladdin (1992). Analyzing a movie also is a literary task because it is also a reflection of human life and also related with feelings, thought, appearance, behavior, happiness, struggle life, sadness, failure, and success. Aladdin movie is an American animated musical fantasy film that produced by Walt Disney Feature Animation and released by Walt Disney Picture. The voice cast features is Scott Weinger as Aladdin, Linda Larkin as Princess Jasmine, Robin Williams as Genie and Jonathan Freeman as Jafar. Aladdin movie was directed by Ron Clements and John Musker. Aladdin was released on November $25^{\text {th }} 1992$ in United States.

Aladdin was about a former street thief called Aladdin who spends all his time in stealing food from the market place in the city of Agrabah. Aladdin's life began to have adventure when he met a girl from the market place. The girl is Princess Jasmine. Princess Jasmine was forced by her father to get marriage soon. Aladdin was falling in love with Princess Jasmine but he couldn't do anything because he just a street thief. His luck beginning to has changes when he retrieves a magical lamp from Cave of Wonders. Genie from the magic lamp grant him three wishes and the Genie will make it happen. Aladdin then takes this chance to 
become a prince to chase princess Jasmine. While the other he didn't know that Jafar the sultan's advisor planned something bad to get back the magic lamp and destroy Aladdin and princess Jasmine's family. The reason why the authors choose this movie is because in this movie the main character Aladdin reveals the aspect of Id, Ego, and Superego from Sigmund Freud theory. From the explanation above the author will analyze the aspect of Id, Ego, and Superego from the main character in Aladdin (1992) movie (Clements \& Musker, 1992).

\section{Psychoanalysis - Sigmund Freud}

Psychoanalysis is the science developed by Sigmund Freud through his experience in treating patients that has mental problems. Psychoanalysis is a psychoanalytic approach that started from the concept of psychology. Psychoanalysis related to the method of psychotherapy to treat mental problems and neurological diseases then developed into personality theory. Psychoanalysis is a psychological theory that related to issues of personality, consciousness, anxiety, dream neurotics, and motivational emotions. Freud stated that there are two kinds consciousness, the first one is the conscious and second is the unconscious (Freud, 1923).

Consciousness is when people realizing with everything that can be sense and seen. Unconscious divided into two, preconscious and unconscious. Preconscious is like perception or imagination that will lead to conscious. Unconscious is the condition where there is no conscious or might happened because of influence. Psychoanalysis theory stated that most of the personality was influenced by the unconscious power.

Freud divided the structure of the human personality into three types consist of the id, the ego, and the superego. These three structural structures did not replace the old structures but perfected them. According to
Sigmund Freud, if the three structures work in a balanced way, humans will show a better character. But if the three structural do not work in balance or are more dominant to one side, there will be war in the human mind or soul (Freud, 1923).

According to Freud human personality is seen as a structure consisting of three elements or systems, namely id, ego, and superego. Although the three systems have their respective functions, completeness, operating principles, dynamism, and mechanism, these three personality systems are interrelated and form a totality. And human behavior is nothing but a product of the interaction between the id, the ego, and the superego (Freud, 1917).

1. Id

Id is one of the main components that existed in humans since birth. Id is aspects of personality that are fully conscious and also include instinctive and primitive behavior. According to Freud (Freud, 1923), the id is the source of all psychic energy, so that it becomes a major component in personality. Id is driven by the pleasure principle, which changes from all needs and desires. If the desire is not immediately satisfied or carried out, it will cause an anxiety in the person. It means that the id is an instinctive thought or desire of someone who if not carried out will cause an anxiety. Id can be controlled by the ego to relieve tension and satisfy desires. The Id aspect is the most basic personality system, the system in which there are innate instincts. For the other two systems, id is a system that acts as a provider or supplier of energy needed by these systems for the operations or activities that they do. In this matter of energy, the id cannot tolerate the buildup of energy which can cause an increase in the stress level of the organism or the whole individual. And however, for individuals the rising tension will be an unpleasant situation. 


\section{Ego}

Ego is the second component that can control the id. Ego is the component that is responsible for dealing with reality, which seeks to meet the needs of the id in an appropriate social and reality way.

\section{Superego}

Superego is a personality system that contains values and rules that are evaluative (involving both good and bad). Superego is formed through the internalization of values or rules by individuals from a number of figures who have a role, influence, or meaning for that individual. Superego activities in individual especially when these activities conflict with the ego, express themselves in certain emotions such as feelings of guilt and regret. Certain attitudes of individuals, such as self-observation, selfcorrection or self-criticism, also originate from the ego.

\section{Character in Aladdin Movie}

1. Aladdin

Aladdin is the son of Cassim and become street child. He is also known as street rat that always spends his time in stealing to get some food to eat. He ends up becoming prince of Agrabah after meeting Jasmine in the street and being recruited by Jafar to get the magic lamp from the Cave of Wonder.

2. Princess Jasmine

Princess Jasmine is the princess of Agrabah who is running or escape from her father wishes. Her father, The Sultan wants her to married a prince soon, but Jasmine flees her palace in revolt her obligation to be married to a prince. While on the market place Princess Jasmine got problem and Aladdin rescued from the market place and later on becomes his wife.

3. Genie
Genie is the fairy that locked in a magic lamp. He is royal with his master who is releases him from the magic lamp and grant the master three wishes. He can be bad guy and good guys. It is depends on who is his master. After he meets Aladdin, Aladdin is the one who is sets him free from the magic lamp curse.

4. Jafar

Jafar is Royal Vizier of Agrabah who has the most enthusiastic to become sultan in the Palace of Agrabah. He spent his time to get the magic lamp. The purpose in getting the magic lamp is to become the strongest sultan and marry Princess Jasmine. But he ends up locked in the magic lamp.

5. The Sultan

The Sultan is the father of Princess Jasmine or the Sultan of the Palace of Agrabah. Sultan is the father who is worrying about his daughter future. So he sets up a marriage planning in case to do the best for his daughter.

6. Abu

Abu is Aladdin's monkey partner with a high-pitcher and can talk a little. Abu is the one who is accompany Aladdin in his bad life. Abu helped Aladdin a lot from the start. In the cave of wonder Abu also help Aladdin to get back the magic lamp from the cheater Jafar.

7. Iago

Iago is the pet and sidekick to Jafar. Lago is the red-plummed sentient bird that helped Jafar to do the bad things.

\section{Synopsis of Aladdin (1992)}

Jafar, the Royal Vizier of the fictional city of Agrabah, placed near the Jordan River, and his parrot Iago seek a lamp hidden within the Cave of Wonders. They tried many times to find the magic lamp in the Cave of Wonders but they always failed. They are told by the Cave of Wonders that there is only one person who is able to enter the cave. The person is the diamond in the rough. Jafar will 
find the diamond in the rough and asked him to gets the magic lamp. While the other side, there is a street rate or former thief in market place of Agrabah called Aladdin. Aladdin is a street rate that spends all his times to stealing food in market place of

Agrabah until one day he met princess Jasmine in the market place. Aladdin helped princess Jasmine from the market's guards that want to arrest Jasmine because of stealing food for a kid. They run and escaped from the guards and hide in Aladdin's house or Aladdin's hideout. In that time they start to know each other, but princess Jasmine hides her identity from Aladdin. Aladdin starts to interest in princess Jasmine and sometime he sneaks to the palace to meet princes Jasmine. Jafar later identifies Aladdin as the diamond in the rough, an Agrabah street urchin. Princess Jasmine of Agrabah, upset that her father requires her to marry a prince instead of one she loves, she escapes the palace and meets Aladdin and his pet monkey, Abu. The palace guards capture Aladdin on Jafar's orders. Jasmine asks Jafar to demand Aladdin's release, but Jafar lies and says that Aladdin has been executed.

Jafar brings Aladdin and Abu to the cave, ordering them to retrieve the lamp. Inside, Aladdin finds a magic carpet and obtains the lamp. In the cave there is a rule that don't touch anything but the lamp. Aladdin focuses on the lamp without touch anything and he got the lamp, while the other side, Abu break the rule and touch the red jewel in the cave, then the cave started to collapses. Aladdin and Abu tried to escape from the cave and the magic carpet help them. The almost out from the cave but they need Jafar's help to pull them out. But Jafar only take the magic lamp and push Aladdin down to the cave. But luckily, Abu was smart thief with his quick hand to take back the magic lamp from Jafar's pocket.

While waiting in the cave, Aladdin was curious about the magic lamp and rubs the magic lamp and free up the Genie. Then Genie grants him three wishes. Aladdin tricks Genie to free them from the cave without using his three wishes. For his first wishes, Aladdin wants to become a prince in case to married princess Jasmine. At Iago's suggestion, Jafar plots to become Sultan by marrying Jasmine. Aladdin, as

"Prince Ali Ababa", arrives in Agrabah with a large host, but Jasmine becomes angry when he discusses her fate with her father the Sultan and Jafar without her. As a means of apologizing, Aladdin takes Jasmine on a ride on the magic carpet. When she deduces his true identity, he convinces her that he only dresses as a peasant to escape the stresses of royal life. After Aladdin brings Jasmine home, the palace guards capture Aladdin on Jafar's behest and throw him into the sea. The Genie appears, intuits that the unconscious Aladdin would want to use his second wish to be rescued, and saves him. Aladdin returns to the palace and exposes Jafar's evil plot. Jafar flees after spotting the lamp and thus discovering Aladdin's true identity. Fearing that he will lose Jasmine if the truth is revealed, Aladdin breaks his promise and refuses to free the Genie. Iago steals the lamp, and Jafar becomes the Genie's new master. He uses his first two wishes to become Sultan and the world's most powerful sorcerer. He then exposes Aladdin's identity and exiles him, Abu, and the carpet to a frozen wasteland. They escape and return to the palace. Jasmine tries to help Aladdin steal the lamp back, but Jafar notices and overpowers the heroes with his magic. Aladdin taunts Jafar for being less powerful than the Genie, tricking Jafar into using his last wish to become an all-powerful genie himself now bound to his new lamp, Jafar ends up trapped inside it, taking Iago with him. With Agrabah returned to normal, the Genie banishes Jafar's lamp and advises Aladdin use his third wish to regain his royal title so the law will allow 
him to stay with Jasmine. Aladdin decides instead to keep his promise and free the Genie. Realizing Aladdin and Jasmine's love, the Sultan changes the law to allow Jasmine to marry whom she chooses. The Genie leaves to explore the world, while Aladdin and Jasmine start their new life together. (Clements \& Musker, 1992)

\section{Literature Review}

In completing this research the writer finds out some previous research that analyses the id, ego, and superego. The first research is Kajian Psikoanalisis Tokoh Dalam Teks Film A La Folie...Pas Du Tout Karya Laetitia Colombani by Friska Brilinani Soraya. In her paper, Friska analysis about the intrinsic approach which is related to plot, character, setting, and theme in A La Folie...Pas Du Tout film. She is also analysis about character psychological condition in A La Folie...Pas Du Tout film in using Sigmund Freud Theory (Soraya, 2015). This previous research is really helped the authors a lot in understanding psychological by Sigmund Freud and supporting the author in completing the paper

\section{Research Method}

The writer collects data in analyzing this research is by quoting Aladdin's movie utterances. In collecting data the writer watched the movie and write down the data that related to the topic that the writer is going to analyze. In this paper the writer is using psychological approach and theory is by Sigmund Freud. This paper is focuses on the main character which is Aladdin. In analyzing the writer is using descriptive analysis because the data is the form of words or statement.

\section{Analysis and Discussion}

1. Analysis Aladdin Character Based on Id Id is driven by the pleasure principle, which changes from all needs and desires. If the desire is not immediately satisfied or carried out, it will cause an anxiety in the person. It means that the id is an instinctive thought or desire of someone who if not carried out will cause an anxiety.

Id consists of a human soul which contains a primitive impulse. Primitive impulses are impulses that exist in humans who want to be immediately carried out and achieved. Below will be explained the Id properties of the Aladdin character.

When Aladdin releases Genie from the magic lamp, Aladdin got three wishes from Genie. From the first Aladdin trick Genie to help him to get out the cave of wonder without using his three wishes. After they got out from the cave of wonder, Aladdin uses his first wish to become a prince and propose to Princess Jasmine.

'Genie: Excuse me? Are you lookin' at me? Did you rub my lamp? Did you wake me up? Did you bring me here? And all of a sudden, you're walking out on me? I don't think so, not right now. You're gettin' your wishes, so sit down! [Abu screeches]

Genie: In case of emergency, the exits are here, here, here, here, anywhere. Keep your hands and arms inside the carpet. We're... outta here!

Genie: Thank you for choosing Magic Carpet for all your travel needs. Don't stand until the rug has come to a complete stop. Thank you. Goodbye now. Good-ye. Thank you. Goodbye. Well, how about that, Mr. Doubting Mustafa?

Aladdin: Oh, you sure showed me. Now, about my three wishes.

Genie: Dost mine ears deceive me? Three? You are down by ONE, boy!

Aladdin: Ah, no. I never actually wished to get out of the cave. You did that on your own.

Genie: [jaw drops] Well, I feel sheepish. All right, you baaad boy, but no more freebie" (Clements R. \&., 1992). 
From the conversation above, Aladdin tricked Genie to shown his super power and also tricked him to take Aladdin and Abu out from the dark cave. The Id showed Aladdin's need or desires to free himself from the cave but in consideration Aladdin did not want to waste his three wishes so he tricked Genie.

\begin{abstract}
“Genie: Ami... C'est l'amour.
Aladdin: But she's the princess. To even have a chance, I'd have to be... Hey, can you make me a prince?

Genie: Let's see here. Chicken à la king? Nope. Alaskan king crab. Ow! I hate it when they do that. Caesar salad. Ah! Et tu, Brute? No! Aha! "To make a prince." Is that an official wish? Say the magic words.
\end{abstract}

Aladdin: Genie, I wish for you to make me a prince.

Genie: All right! Yo, yo! Woof! Woof! First, that fez-and-vest combo is much too third century. These patches. What are we trying to say, beggar? No. Let's work with me here. Ooh. I like it. Muy macho. Now, it still needs something. What does it say to me? It says mode of transportation. Excuse me, monkey boy. Aqui. Over here" (Clements R. \&., 1992).

The conversation above is proving that Aladdin has a dream to become a prince and propose to Princess Jasmine. But because of his material condition, Aladdin did not have anything and only a famous thief. So, Aladdin asked Genie to make him become a prince and Genie complete his wishes. Now he becomes non formal Prince Ali of Ababwa and went back to Agrabah to get his future wife.

\section{Analysis Aladdin Character Based on Ego}

Ego is the second component that can control the id. Ego is the component that is responsible for dealing with reality. According to Sigmund Freud, the ego develops from the id and ensures that the impulse of the id can be expressed in an acceptable way in the real world. The ego works on the principle of reality, which seeks to meet the needs of the id in an appropriate social and reality way. The conversation below explained Ego in Aladdin character.

"Prince Ali: Sultan? They want me to be Sultan?

Genie: Huzzah! \& Hail the conquering hero! $\delta[\delta$ Stars and Stripes Forever plays] Aladdin, you've just won the heart of the princess. What are you gonna do next?

[sighs deeply]

Genie: [whispering] Psst. Your line is, "I'm going to free the genie." Anytime.

Prince Ali: Genie, I can't.

Genie: Sure you can. You just go, "Genie, I wish you free."

Prince Ali: I'm serious. Look, I'm sorry. I really am. But they wanna make me sultan. No. They wanna make Prince Ali sultan. Without you, I'm just Aladdin.

Genie: Al, you won.

Prince Ali: Because of you. The only reason anyone thinks I'm worth anything is because of you. What if they find out I'm not really a prince? What if Jasmine finds out? I'd lose her. Genie, I can't keep this up on my own. I can't wish you free" (Clements R. \&., 1992).

In this section, the ego begins to look stronger because Aladdin dream is marrying princess jasmine. He was happy and scared. Aladdin also has the thought to break his promised to Genie before because of his selfishness. But Genie was pleased when he heard that Aladdin was going to become a sultan. Genie then felt that he has completed Aladdin's second request. He then asked what Aladdin wanted next, as his promised before, Aladdin would free the genie from the magic lamp. But Aladdin was actually afraid that if he let go of Genie, he was afraid that Jasmine would one day find out who Aladdin really was and would leave Aladdin with his lies. Aladdin then decided to keep his last wishes 
to cover the truth if Jasmine finds out the real Aladdin in the future. He finally said he would not release Genie and Genie felt disappointed and cheated because of Aladdin selfishness and has a fight with Aladdin.

\section{Analysis Aladdin Character Based on Superego}

Superego is the aspect of personality that holds all moral internalization standards and ideals. Superego provides a way to make judgments. Superego acts to improve our behavior from bad to better. Superego covered the desire in Ego that causes the bad impact for a person and helped the character to decide and choose the right choice without causing harm to the people around. Here the superego in Aladdin character.

"Aladdin: Jasmine... I'm sorry I lied to you about being a prince.

Jasmine: I know why you did.

Aladdin: But, Genie, what about your freedom?

Genie: Hey, it's only an eternity of servitude. This is love. Al, you're not gonna find another girl like her in a million years. Believe me, I know. I've looked.

Aladdin: Jasmine, I do love you, but I got to stop pretending to be something I'm not.

Jasmine: I understand.

Aladdin: Genie, I wish for your freedom.

Genie: One bonafide prince pedigree coming up. What?

Aladdin: Genie, you're free.

Genie: I'm free. I'm free. Quick. Quick.

Wish for something outrageous. Say, "I want the Nile." Try that.

Aladdin: Uh, I wish for the Nile.

Genie: No way! [laughing gleefully]

Oh, does that feel good! Oh! I'm free!

I'm free at last! I'm hittin' the road. I'm

off to see the world. I'm..." (Clements, R., \& Musker, J, 1992).

Aladdin: Genie, I'm... I'm gonna miss you.
Genie: Me, too, Al. [sniffles] No matter what anybody says, you'll always be a prince to me (Clements R. \&., 1992).

In this part, Aladdin felt regret. He regrets being selfish and lied to Jasmine about his true identity and also he has hurt genie. Aladdin then honestly told Princess Jasmine that she was just a street thief who had nothing. He then also freed the genie from his magic lamp. As you can see that superego makes Aladdin felt regret with what he did before and superego also a personality system that breaks away from the ego and become better character.

\section{Conclusion}

From the discussion above it can be seen that the character id, ego, and superego are structural that govern how a person will do. How good character is formed. Even though Aladdin is an orphan and always spends time stealing for the sake of his life, he finally dares to be honest with Princess Jasmine that he is not a rich prince. He gave up his ego to get the best.

\section{References}

Clements, R., \& Musker, J. (Directors). (1992). Aladdin [Motion Picture]. United States: Disney.

Freud, S. (1917). A General Introduction to Psychoanalysis. Austria: PDF BooksWorld.

Freud, S. (1921). Group Psychology and the Analysis of the Ego. Austria: International Psychoanalytic Publishing House.

Freud, S. (1923). The Ego and The ID. Austria: W. W. Norton \& Company.

Lye, J. (1996). Psychoanalysis and Literature. Canada: Brock University.

Soraya, F. B. (2015). Kajian Psikoanalisis Tokoh Dalam Teks Film A La Folie...Pas

Du Tout Karya Laetitia Colombani [Unpublished bachelor's thesis]. Universitas Negeri Yogyakarta. 